\title{
Helicobacter pylori colonization and oral health in children
}

\author{
Colonizarea cu Helicobacter pylori şi sănătatea orală la copii \\ Vasile Valeriu LUPU, Gabriela PĂDURARU, Anca ADAM, Ana-Maria DĂBULEANU, \\ Ancuța IGNAT, Marin BURLEA
}

Disciplina Pediatrie, Universitatea de Medicină şi Farmacie „Gr.T. Popa“, Iaşi, România

\begin{abstract}
Helicobacter pylori (H. pylori) is a microaerophilic gram-negative bacterium infecting approximately one-half of the world's population. The oral cavity and dental plaque may be a reservoir for $\mathrm{H}$. pylori infection. Diagnosis of $\mathrm{H}$. pylori infection in children differs from that of adults. Although $\mathrm{H}$. pylori has long been known to be detected in the oral cavity, the significance of such findings are controversial. Oral H. pylori may play an important role in re-infection of the gastric mucosa. The gold standard for eradicating $\mathrm{H}$. pylori infection is standard triple therapy. The studies have shown promising results in the management of both oral and gastric $\mathrm{H}$. pylori.
\end{abstract}

Keywords: H. pylori, oral health, child

\section{REZUMAT}

Helicobacter pylori (H. pylori) este o bacterie microaerofilă gram-negativă ce infectează aproximativ o jumătate din populația planetei. Cavitatea orală şi placa dentară pot constitui un rezervor pentru infecția cu H. pylori. Diagnosticul infecției cu H. pylori la copii diferă față de cel de la adulți. Deşi este cunoscut de mult timp faptul că $\mathrm{H}$. pylori poate fi detectat în cavitatea orală, semnificația acestui lucru rămâne controversată. Prezența H. pylori la nivelul cavității orale poate juca un rol important în reinfecția mucoasei gastrice. Gold standardul utilizat pentru eradicarea infecției $c u \mathrm{H}$. pylori este terapia triplă standard. Studiile au prezentat rezultate promițătoare în managementul ambelor infecții $\mathrm{cu} \mathrm{H}$. pylori, atât gastrică, cât şi orală.

Cuvinte cheie: H. pylori, sănătate orală, copil

\section{INTRODUCERE}

Helicobacter pylori (H. pylori) este o bacterie microaerofilă, gram-negativă ce infectează aproximativ o jumătate din populația planetei (1). În 1982, Barry Marshall și Robin Warren au izolat pentru prima oară în cultură microorganismul sub denumirea de Campylobacter pylori. A fost redenumit în 1989 și a fost recunoscut ca fiind asociat cu gastrita cronică (gastrită cronică superficială, gastrită cronică activă), ulcerul peptic, adenocarcinomul gastric și limfomul cu celule mici asociat mucoaselor (MALT) (2). Majoritatea persoanelor infectate cu $\mathrm{H}$. pylori sunt asimptomatice și nu vor dezvolta niciodată boala. Diagnosticul și tratamentul infecției cu H. pylori la copii este important, deoarece bacteria se poate asocia și cu alte patologii precum anemia prin deficiență de fier și malnutriția $(3,4)$. Sunt diferențe între copii și adulți în ceea ce privește epidemiologia, patogenia, diagnosticul clinic și paraclinic și strategiile terapeutice. 


\section{Efectele colonizării cu Helicobacter pylori asupra sănătății orale la copii}

H. pylori poate fi transmis pe cale orală și a fost detectat în placa de la nivelul cavității orale și salivă. Cavitatea orală și placa dentară pot constitui un rezervor pentru infecția cu $\mathrm{H}$. pylori (6). Un număr mare de studii au investigat relația dintre infecția cu $H$. pylori, cariile dentare, igiena orală, obiceiurile alimentare și parametrii salivari. Parametrii bacteriei în placa dentară în numeroase studii variază între 0-100\%, în funcție de modul de prelevare a probelor și diferitele metode utilizate pentru detectarea microorganismului în placa dentară (testul ureazei, reacția de polimerizare în lanț, analize imunologice, citologie și culturi) $(5,7)$.

Într-un studiu realizat pe 70 de copii cu vârste cuprinse între 5-15 ani, prezența $H$. pylori în placa dentară a fost raportată ca fiind de $82 \%$ la pacienți cu gastrită (8). Autorii studiului au ajuns la concluzia conform căreia cavitatea orală poate reprezenta un rezervor important pentru $H$. pylori și că ar putea constitui o sursă de reinfecție (8-10). Igiena orală riguroasă ar putea contribui pozitiv la tratamentul gastritei.

Sunt autori care au arătat o asociere între cariile dentare și infecția orală cu $H$. pylori (11). Aceștia au sugerat faptul că infecția bacteriană în cavitatea orală este asociată cu cariile dentare și cu o igienă dentară deficitară (12). În contrast, există studii care au demonstrat că bacteria este în mod frecvent prezentă în cavitatea orală, deși caracterul colonizării orale nu este clar, iar relația cu simptomele dispeptice și comportamentul alimentar nu este bine definit. Rezultatele acestor studii au indicat că prezența $H$. pylori în cavitatea orală nu este asociată în mod semnificativ cu infecțiile gastrice, sănătatea parodontală sau cu nivelele serice ale grelinei și gastrinei (13).

Unii autori sugerează că $H$. pylori în cavitatea orală poate contribui la etiologia stomatitei aftoase recurente (14). Există similarități între caracteristicile histologice ale ulcerelor peptice și cele ale ulcerelor orale aftoase. Aceste ulcere orale răspund la tratamentul cu antibiotic cu spectru larg (tetracicline), astfel încât autorii au sugerat faptul că $H$. pylori ar putea juca un rol în dezvoltarea ulcerelor aftoase recurente.

Este precizat faptul că $H$. pylori ar putea juca un rol în dezvoltarea glositei atrofice sau a leziunilor canceroase $(15,16)$.

\section{Diagnosticul infecției cu Helicobacter pylori}

Metodele non-invazive de diagnostic a H. pylori cu o acuratețe înaltă sunt: testul respirator cu uree, antigenul $H$. pylori fecal și anticorpii anti-H. pylori din ser, urină sau salivă (3).

Testul respirator poate fi realizat în siguranță și nu necesită un examinator experimentat. Testul este înalt specific și sensibil pentru copiii mai mari de 6 ani (acest test necesită cooperarea pacientului). Este dificil de realizat la copii mici, sugari sau copii cu deficiențe fizice (3). Un review sistematic a arătat că testul respirator are o sensibilitate și specificitate mai mari decât serologia IgG și testul antigenului $H$. pylori fecal (17). Copiii mai mici de 6 ani sunt stimulați să își clătească cavitatea orală cu lichide după ingestia de 13 C-uree pentru a reduce degradarea de către flora orală.

Testul antigenului fecal $H$. pylori poate fi realizat fără cooperarea activă a copiilor. Pentru a detecta $H$. pylori în proba înghețată este folosit un procedeu imunologic. Testul este mai puțin costisitor decât testul respirator și acuratețea rezultatelor este independentă de vârstă $(3,18)$. Ghidurile recomandă testul antigenului fecal $H$. pylori ca fiind un test capabil să determine dacă infecția a fost eradicată sau nu.

Anticorpii anti-H. pylori din ser, urină sau salivă au fost utilizați în special pentru studii epidemiologice (19). Aceste teste (bazate pe detectarea anticorpilor IgG și $\operatorname{lgA}$ ) nu sunt utile în practica clinică la copii (3). Sensibilitatea și specificitatea în detectarea anticorpilor anti-H. pylori la copii, variază (3). Anticorpii specifici se pot menține pozitivi mult timp după eradicarea infecției. Testul Cassette pentru H. pylori din salivă folosește anticorpi monoclonali pentru a identifica ureaza specifică din salivă. Studiile bazate pe rezultatele testelor PCR utilizate pentru detectarea $H$. pylori în cavitatea orală au prezentat concluzii variabile (20).

Metoda de diagnostic invaziv a infecției cu $\mathrm{H}$. pylori este reprezentată de esofagogastroduodenoscopie (EGD). Indicațiile de diagnostic prin EGD la pacienții pediatrici sunt: scăderea ponderală, falimentul creșterii, anemia inexplicabilă, durerea abdominală cu suspiciune de boală organică, disfagia sau odinofagia, ingestia de substanțe caustice, vărsăturile recurente fără cauze cunoscute, hematemeza, diareea cronică inexplicabilă, suspiciunea de boală grefă contra gazdă, boala cronică de reflux gastro-esofagian, pentru excluderea altor patologii sau supravegherea unui esofag Barret (21).

Pentru diagnosticul inițial, prezența H. pylori este dovedită prin realizarea testului rapid al ureazei și prin examenul histopatologic al biopsiilor recoltate. Se recomandă ca pentru $H$. pylori, cultura să fie obținută în același timp. La 
copii, este acceptabilă diagnosticarea infecției cu $H$. pylori când histologia sau testul rapid al ureazei sunt pozitive sau când cultura pentru $H$. pylori este pozitivă (3). Infecția cu H. pylori ar trebui bănuită la copii atunci când sunt modificări nodulare la nivelul antrumului sau eroziuni și ulcerații în duoden la endoscopie (3). În infecția cronică cu H. pylori, noduli mici pot fi observați la endoscopie în 44-67\% dintre cazurile de infecție cu $H$. pylori la copii (22).

\section{Tratamentul infecției cu Helicobacter pylori la copii}

H. pylori supraviețuiește în biofilmurile dentare, deoarece condițiile paraodontale promovează un habitat viabil pentru acest microorganism. Bacteria producătoare de urează poate să-și îmbunătățească viabilitatea în mediul parodontal, iar antibioticele au o penetranță slabă în structura biofilmului bacterian. A fost raportat faptul că în cavitatea orală bacteria preferă placa supragingivală (23). Sănătatea parodontală precară poate fi asociată cu infecțiile cu H. pylori din cavitatea orală (24).

Rezistența la antibiotice este o importantă cauză de eșec a terapiei infecției cu $H$. pylori. Prima linie a strategiilor de eradicare este: tripla terapie cu un inhibitor al pompei de protoni (IPP) amoxicilină + imidazol sau IPP + amoxicilină + claritromicină sau săruri de bismut + amoxicilină + imidazol sau terapia secvențială. Terapia secvențială implică terapia duală cu IPP și amoxicilină pentru 5 zile urmată secvențial de 5 zile de triplă terapie (un IPP cu claritromicină și metronidazol/tinidazol). Se recomandă ca durata triplei terapii să fie de 7-14 zile (3).

Gold standardul pentru eradicarea infecției cu $H$. pylori este reprezentat de tripla terapie standard, dar mai multe studii au arătat un declin constant al eficacității eradicării $H$. pylori prin această metodă (aproximativ $50 \%)(25,26)$. Acest declin a fost atribuit unei rezistențe în creștere la claritromicină și, de asemenea, unei complianțe scăzute la tratament. Deși s-a constatat o îmbunătățire în eradicarea $H$. pylori odată cu introducerea probioticelor adjuvante, folosirea acestora ca monoterapie a dus la reducerea încărcăturii bacteriene, dar nu și la eradicarea $H$. pylori (27-29). Autorii mai multor studii au ajuns la concluzia că suplimentarea terapiei cu probiotice duce la o creștere a ratei de eradicare a infecției cu $H$. pylori atât la adulții, cât și la copiii asiatici sau non-asiatici, mai mare decât cea produsă de tripla terapie singură (29).

Un număr considerabil de studii a arătat faptul că atunci când pacienții au primit tratament pentru infecția gastrică cu $H$. pylori, medicamentele nu au eliminat și $H$. pylori din cavitatea orală. Unele studii au evaluat efectele tratamentului sistemic de eradicare a $H$. pylori asupra $H$. pylori din cavitatea orală. Majoritatea acestora au raportat faptul că eradicarea bacteriană sistemică în absența oricărei forme de tratament paraodontal, deși este eficientă în tratarea infecției gastrice, are un efect minim asupra infecției orale cu $H$. pylori $(5,30)$. De asemenea, un alt studiu a arătat că eradicarea sistemică a $H$. pylori este aproape lipsită de impact asupra $H$. pylori de la nivel oral (5).

Autorii unui studiu realizat pe un lot de 82 de pacienți cu $H$. pylori în placa dentară au comparat efectele triplei terapii și cele ale terapiei parodontale, singure sau în combinație. Aceștia au obținut cele mai bune rezultate în eradicarea $H$. pylori în grupul unde a fost aplicată doar terapia parodontală, urmate de grupul care a primit terapie combinată, în timp ce $H$. pylori a persistat în placa dentară a tuturor pacienților care au primit doar tripla terapie (31). Acest studiu a ilustrat rezultate promițătoare în managementul terapiilor infecțiilor orale și gastrice cu H. pylori.

Studii realizate pe rozătoare și oameni, ce au utilizat vaccinarea orală cu adjuvanți ai exotoxinei bacteriene, au demonstrat un real potențial în limitarea colonizării cu $H$. pylori a stomacului. S-a demonstrat că vaccinarea are o eficacitate de peste $70 \%$. Autorii au ajuns la concluzia că vaccinarea ar putea constitui o strategie efectivă în reducerea semnificativă a $H$. pylori asociat bolilor la copiii din toată lumea (32).

\section{CONCLUZII}

Cavitatea orală este un important rezervor extragastric pentru $H$. pylori, care poate constitui atât o sursă de reinfecție, cât și o cale de transmisie. Studiile au ilustrat rezultate promițătoare în managementul infecțiilor orale și gastrice cu H. pylori. 


\section{BIBLIOGRAFIE}

1. Megraud F., Brassens-Rabbe M.P., Denis F. Seroepidemiology of Campylobacter pylori infection in various populations. $J$ Clin Microbiol 1989; 27:1870-1873.

2. Dunn B.E., Cohen H., Blaser M.J. Helicobacter pylori. Clin Microbiol Rev. 1997; 10:720-741.

3. Koletzko S., Jones N.L., Goodman K.J., Gold B., Rowland M., Cadranel S., et al. $\mathrm{H}$ pylori Working Groups of ESPGHAN and NASPGHAN. Evidence-based guidelines from ESPGHAN and NASPGHAN for Helicobacter pylori infection in children. J Pediatr Gastroenterol Nutr. 2011; 53:230-243.

4. Yang H.R. Updates on the Diagnosis of Helicobacter pylori Infection in Children: What Are the Differences between Adults and Children? Pediatr Gastroenterol Hepatol Nutr. 2016 Jun; 19(2): 96-103.

5. Anand P.S., Kamath K.P., Anil S. Role of dental plaque, saliva and periodontal disease in Helicobacter pylori infection. World J Gastroenterol. 2014 May 21; 20(19): 5639-5653.

6. Berroteran A., Perrone M., Correnti M., Cavazza M.E., Tombazzi C., Goncalvez R., et al. Detection of helicobacter pylori DNA in the oral cavity and gastroduodenal system of a venezuelan population. $J$ Med Microbiol. 2002; 51(9):764-770.

7. Gurbuz A.K., Ozel A.M., Yazgan Y., Celik M., Yildirim S. Oral colonization of Helicobacter pylori: Risk factors and response to eradication therapy. South Med J. 2003; 96(3):244-247.

8. Dane A., Gurbuz T. Clinical Comparative Study of the Effects of Helicobacter Pylori Colonization on Oral Health in Children. Pak J Med Sci. 2016 Jul-Aug; 32(4): 969-973.

9. Hu W., Cao C., Meng H., Zhang J., Ma D., Zhang L. Detection and analysis of helicobacter pylori in oral cavity and stomach from chronic gastritis patients. Zhonghua Yi Xue Za Zhi. 2002; 82(15):1037-1041.

10. Mravak-Stipetic M., Gall-Troselj K., Lukac J., Kusic Z., Pavelic K., Pavelic J. Detection of helicobacter pylori in various oral lesions by nested polymerase chain reaction (pcr) J Oral Pathol Med. 1998; 27(1):1-3.

11. Namiot Z., Namiot D.B., Kemona A., Stasiewicz J. Effect of antibacterial therapy and salivary secretion on the efficacy of helicobacter pylori eradication in duodenal ulcer patients. Oral Surg Oral Med Oral Pathol Oral Radiol Endod. 2004; 97(6):714-717.

12. Liu P., Yue J., Han S., Deng T., Fu C., Zhu G., et al. A cross-sectional survey of dental caries, oral hygiene, and helicobacter pylori infection in adults. Asia Pac J Public Health. 2013; 25(4 Suppl):49S-56S.

13. Czesnijiewicz-Guzik M., Bielanski W., Guzik T.J., et al. Helicobacter pylori and its implications in gastric infection, periodontal health, immunology and dyspepsia. Journal of Physiology and Pharmacology 2005; 56(supp6):77-89.

14. Riggio M.P., Lennon A., Wray D. Detection of Helicobacter pylori DNA in recurrent aphthous stomatitis tissue by PCR. J Oral Pathol Med 2000; 29:507-513.

15. Okuda K., Ishihara K., Miura T., et al. Helicobacter pylori may have only a transient presence in the oral cavity and on the surface of oral cancer. Microbiol Immunol 2000; 44:385-388.

16. Gall-Troselj K., Mravak-Stipetic M., Jurak, et al. Helicobacter pylori colonization of tongue mucosa-increased incidence in atrophic glossitis and burning mouth syndrome (BMS). J Oral Pathol Med 2001; 30: 560-563

17. Shiota S., Cruz M., Abreu J.A.J., et al., "Virulence genes of Helicobacter pylori in the Dominican Republic," Journal of Medical Microbiology 2014; 63(9):11891196.

18. Koletzko S. Noninvasive diagnostic tests for Helicobacter pylori infection in children. Can J Gastroenterol 2005;19:433-9.

19. Guarner J., Kalach N., Elitsur Y., Koletzko S. Helicobacter pylori diagnostic tests in children: review of the literature from 1999 to 2009. Eur J Pediatr. 2010; 169:15-25.

20. Patel S.K., Pratap C.B., Jain A.K., et al. Diagnosis of Helicobacter pylori: What should be the gold standard? World J Gastroenterol. 2014 Sep 28; 20(36): 12847-12859.

21. Tringali A., Thomson M., Dumonceau J.M., et al. Pediatric gastrointestinal endoscopy: European Society of Gastrointestinal Endoscopy (ESGE) and European Society for Paediatric Gastroenterology Hepatology and Nutrition (ESPGHAN) Guideline Executive summary. DOI http://dx.doi. org/10.1055/s-0042-111002. Published online: 2016.
22. Prieto G., Polanco I., Larrauri J., et al. Helicobacter pylori infection in children: clinical, endoscopic, and histologic correlations. J Pediatr Gastroenterol Nutr. 1992; 14:420-425.

23. Umeda M., Kobayashi H., Takeuchi Y., Hayashi J., Morotome-Hayashi Y., Yano K., Aoki A., Ohkusa T., Ishikawa I. High prevalence of Helicobacter pylori detected by PCR in the oral cavities of periodontitis patients. J Periodontol. 2003; 74:129-134.

24. Yee J.K.C. Helicobacter pylori colonization of the oral cavity: A milestone discovery. World J Gastroenterol. 2016 Jan 14; 22(2): 641-648.

25. Francavilla R., Lionetti E., Castellaneta S.P., et al. Improved efficacy of 10-Day sequential treatment for Helicobacter pylori eradication in children: a randomized trial. Gastroenterology. 2005; 129(5):1414-1419.

26. Huang J., Zhou L,. Geng L., et al. Randomised controlled trial: sequential vs. standard triple therapy for Helicobacter pylori infection in Chinese children-a multicentre, open-labelled study. Aliment Pharmacol Ther. 2013; 38(10):1230-1235.

27. Namkin K., Zardast M., Basirinejad F. Saccharomyces boulardii in Helicobacter Pylori eradication in children: a randomized trial from Iran. Iran J Pediatr. 2016; 26(1):e3768.

28. Wang K.Y., Li S.N., Liu C.S., et al. Effects of ingesting Lactobacillus- and Bifidobacterium-containing yogurt in subjects with colonized Helicobacter pylori. Am J Clin Nutr. 2004; 80(3):737-741.

29. Lau C.S.M., Ward A., Chamberlain R.S. Probiotics improve the efficacy of standard triple therapy in the eradication of Helicobacter pylori: a meta-analysis. Infect Drug Resist. 2016; 9: 275-289.

30. Gao J., Li Y., Wang Q., Qi C. Zhu S. Correlation between distribution of Helicobacter pylori in oral cavity and chronic stomach conditions. J Huazhong Univ Sci Technolog Med Sci. 2011; 31:409-412.

31. Butt A.K., Khan A.A., Suleman B.A., Bedi R. Randomized clinical trial of Helicobacter pylori from dental plaque. Br J Surg. 2001; 88:206.

32. Blanchard T.G., Czinn S.J. Identification of Helicobacter pylori and the evolution of an efficacious childhood vaccine to protect against gastritis and peptic ulcer disease. Pediatr Res. 2016 Nov 2. doi: 10.1038/ pr.2016.199. 